\title{
Faktor risiko yang berhubungan dengan kejadian kelainan bawaan pada neonatus di RSUP Prof Dr. R. D. Kandou Manado
}

\author{
${ }^{1}$ Evan G. Polii \\ ${ }^{2}$ Rocky Wilar \\ ${ }^{2}$ Adrian Umboh
}

\author{
${ }^{1}$ Kandidat Skripsi Fakultas Kedokteran Universitas Sam Ratulangi Manado \\ ${ }^{2}$ Bagian Ilmu Kesehatan Anak Fakultas Kedokteran Universitas Sam Ratulangi Manado \\ Email: polii.evan@yahoo.com
}

\begin{abstract}
Nowadays, problems of the quality of the child life is the main priority in national health program, inter alia congenital anomaly which is defined as structural or functional anomaly (example metabolic disorders) that occurs during intrauterine life and can be identified before birth, at birth, or after birth. This study was aimed to find out the risk factors that related to the occurrence of congenital anomalies in the neonati at Prof . Dr. R. D. Kandou Hospital Manado. This was a descriptive retrospective study. Total samples were 66 neonates that fulfilled the inclusion criteria as follows: neonates who were born and taken cared at Prof. Dr. R. D. Kandou Hospital Manado. The results showed that maternal risk factors had a major role to the occurrence of congenital anomalies. Conclusion: Maternal infection during pregnancy was the most common risk factor, however, several congenital anomalies had unknown risk factor.
\end{abstract}

Keywords: neonates, congenital anomalies, maternal risk factor

\begin{abstract}
Abstrak: Pada zaman sekarang ini masalah kualitas hidup anak merupakan prioritas utama bagi program kesehatan nasional. Salah satu faktor yang memengaruhi kualitas hidup anak ialah adanya kelainan bawaan yaitu anomali struktural atau fungsional (misalnya gangguan metabolisme) yang terjadi selama hidup intrauterin dan dapat diidentifikasi sebelum lahir, saat lahir, atau di kemudian hari. Penelitian ini bertujuan untuk mengetahui faktor risiko yang berhubungan dengan kejadian kelainan bawaan pada neonatus di RSUP Prof. Dr. R. D. Kandou Manado. Jenis penelitian ialah deskriptif retrospektif. Sampel sebanyak 66 neonati dengan kriteria inklusi neonatus yang lahir dan dirawat di RSUP Prof Dr. R. D. Kandou Manado. Hasil penelitian memperlihatkan bahwa faktor risiko ibu berperan penting terhadap kejadian kelainan bawaan. Simpulan: Infeksi ibu selama kehamilan merupakan faktor risiko ibu yang paling sering ditemukan pada kelainan bawaan. Walalupun demikian, terdapat juga faktor-faktor yang tidak diketahui yang memengaruhi kejadian kelainan bawaan.
\end{abstract}

Kata kunci: neonatus, kelainan bawaan, faktor risiko ibu

Kelainan bawaan adalah anomali struktural atau fungsional yang terjadi selama hidup intrauterin. ${ }^{1}$ Bayi baru lahir yang menderita kelainan bawaan akan menderita seumur hidup karena ketidakmampuan dalam melaksanakan aktivitas sehari-hari ataupun karena masalah kosmetik, mereka yang mengalami kelainan bawaan harus diberikan penanganan dan pertolongan sosial yang baik untuk meningkatkan kualitas hidup mereka agar mereka dapat bergaul dengan lingkungan. ${ }^{2}$ Menurut data yang didapatkan di Pakistan, faktor risiko tersering yang menyebabkan kelainan bawaan ialah faktor ibu yang terbagi atas 3 bagian, yaitu faktor sosioekonomi, faktor nutrisi dan faktor pendidikan. ${ }^{3}$ The Centers for Disease Control and Prevention (2007) memperkirakan kelainan bawaan terjadi 
pada 1:33 bayi yang lahir setiap tahun di Amerika Serikat. World Health Organization menyatakan bahwa 260.000 kematian neonatal di seluruh dunia $(7 \%)$ disebabkan karena kelainan bawaan. ${ }^{4}$ Penelitian Maramis et al. ${ }^{5}$ melaporkan bahwa di RSUP Prof. Dr. R. D. Kandou terdapat jumlah responden sebanyak 53 anak terdiri dari 34 anak laki-laki dan 19 anak perempuan. Jenis Penyakit Jantung Bawaan (PJB) yang paling banyak diderita ialah jenis Atrial Septal Defect (ASD). Kebanyakan penderita mengalami gizi kurang $(54,7 \%)$, diikuti dengan gizi buruk $(37,8 \%)$ dan gizi baik $(7,5 \%) .^{5}$

\section{METODE PENELITIAN}

Jenis penelitian ini ialah deskriptif retrospektif. Penelitian dilaksanakan di Bagian Ilmu Kesehatan Anak dan Bagian Rekam Medik RSUP Prof. Dr. R. D. Kandou Manado periode SeptemberNovember 2016.

Sampel dalam penelitian ini ialah 66 neonati dengan kriteria inklusi neonatus yang lahir dan dirawat di RSUP Prof. Dr. R. D. Kandou Manado. Variabel penelitian ialah kelainan bawaan dan faktor risiko yang berhubungan dengan kejadian kelainan bawaan.

\section{HASIL PENELITIAN}

Berdasarkan hasil penelitian yang dilakukan secara retrospektif di Bagian Ilmu Kesehatan Anak dan Bagian Rekam Medik dalam kurun waktu September 2016-November 2016 terdapat 266 neonati yang didiagnosis dengan kelainan bawaan dan hanya 66 neonati yang memenuhi kriteria inklusi. Hal ini disebabkan oleh berbagai faktor, diantaranya neonati yang merupakan rujukan dari rumah sakit lain atau neonati dengan data rekam medik tidak lengkap sehingga yang tercatat dengan data yang lengkap hanya 66 dari 266 neonati.

Distribusi neonati dengan kelainan bawaan berdasarkan tahun dapat dilihat pada Tabel 1. Pada tahun 2015 terdapat 54 kasus kelainan bawaan pada neonati $(81,8 \%)$ dan tahun 2016 (Juli) terdapat 12 kasus kelainan bawaan pada neonati $(18,2 \%)$. Jumlah keseluruhan neonati dengan kelainan bawaan yang lahir di RSUP Prof. Dr. R. D. Kandou Manado periode Januari 2015-Juli 2016 ialah 66 kasus $(100 \%)$.

Tabel 1. Distribusi neonatus dengan kelainan bawaan berdasarkan tahun

\begin{tabular}{ccc}
\hline Tahun & Jumlah & $(\boldsymbol{\%})$ \\
\hline 2015 & 54 & 81,8 \\
2016 (Juli) & 12 & 18,2 \\
Total & 66 & 100 \\
\hline
\end{tabular}

Pada Tabel 2 terlihat bahwa neonati dengan kelainan bawaan dengan jenis kelamin laki-laki lebih banyak yaitu 48 orang $(72,7 \%)$ dibandingkan dengan jenis kelamin perempuan yaitu 18 orang $(27,3 \%)$.

Tabel 2. Distribusi neonati dengan kelainan bawaan berdasarkan jenis kelamin

\begin{tabular}{ccc}
\hline Jenis kelamin & Jumlah & $\mathbf{( \% )}$ \\
\hline Laki-laki & 48 & 72,7 \\
Perempuan & 18 & 27,3 \\
Total & 66 & 100 \\
\hline
\end{tabular}

Pada Tabel 3 terlihat bahwa jumlah kehamilan tunggal 63 neonati $(95,4 \%)$, sedangkan jumlah kehamilan kembar hanya 3 neonati $(4,6 \%)$.

Tabel 3. Distribusi neonati dengan kelainan bawaan berdasarkan tipe kehamilan

\begin{tabular}{ccc}
\hline Tipe kehamilan & Jumlah & $\mathbf{( \% )}$ \\
\hline Kehamilan tunggal & 63 & 95,4 \\
Kehamilan kembar & 3 & 4,6 \\
Total & 66 & 100 \\
\hline
\end{tabular}

Pada Tabel 4, ibu yang mengonsumsi aspirin sebanyak 9 orang $(13,6 \%)$, fenitoin dan carbamazepine 2 orang (3\%), diazepam 1 orang $(1,6 \%) ; 52$ orang ibu $(78,8 \%)$ tidak mengonsumsi obat-obatan.

Pada Tabel 5, ibu yang merokok berjumlah 5 orang $(7,6 \%)$ dan ibu yang tidak merokok 61 orang $(92,4 \%)$.

Pada Tabel 6, ibu yang mengonsumsi alkohol berjumlah 5 orang $(7,6 \%)$ dan ibu 
yang tidak mengonsumsi alkohol 61 orang $(92,4 \%)$.

Tabel 4. Distribusi neonati dengan kelainan bawaan berdasarkan konsumsi obat-obatan

\begin{tabular}{ccc}
\hline Jenis Obat & Jumlah & $(\boldsymbol{\%})$ \\
\hline Aspirin & 9 & 13,6 \\
Fenitoin & 2 & 3 \\
Carbamazepine & 2 & 3 \\
Diazepam & 1 & 1,6 \\
Tidak mengonsumsi & 52 & 78,8 \\
obat-obatan & & \\
Total & 66 & 100 \\
\hline
\end{tabular}

Tabel 5. Distribusi neonatus dengan kelainan bawaan berdasarkan konsumsi rokok

\begin{tabular}{ccc}
\hline Rokok & Jumlah & $\mathbf{( \% )}$ \\
\hline Merokok & 5 & 7,6 \\
Tidak Merokok & 61 & 92,4 \\
Total & 66 & 100 \\
\hline
\end{tabular}

Tabel 6. Distribusi neonati dengan kelainan bawaan berdasarkan konsumsi alkohol

\begin{tabular}{ccc}
\hline Alkohol & Jumlah & $\mathbf{( \% )}$ \\
\hline $\begin{array}{c}\text { Mengkonsumsi } \\
\text { Alkohol }\end{array}$ & 5 & 7,6 \\
$\begin{array}{c}\text { Tidak mengkonsumsi } \\
\text { Alkohol } \\
\text { Total }\end{array}$ & 61 & 92,4 \\
\hline
\end{tabular}

Pada Tabel 7, ibu yang terkena infeksi sebanyak 20 orang (30,3\%), sedangkan ibu yang tidak terkena infeksi 46 orang $(69,7 \%)$.

Tabel 7. Distribusi neonati dengan kelainan bawaan berdasarkan infeksi ibu selama kehamilan

\begin{tabular}{ccc}
\hline Infeksi & Jumlah & $\mathbf{( \% )}$ \\
\hline Terkena infeksi & 20 & 30,3 \\
Tidak terkena & 46 & 69,7 \\
infeksi & & \\
Total & 66 & 100 \\
\hline
\end{tabular}

Pada Tabel 8 didapatkan bahwa dari 66 neonati dengan kelainan bawaan terdapat 9 orang ibu $(13,6 \%)$ berusia $\leq 20$ tahun yang melahirkan neonati dengan kelainan bawan, 23 orang ibu $(34,8 \%)$ berusia 21-29 tahun, 19 orang ibu $(28,8 \%)$ berusia 30-39 tahun, dan 15 orang ibu $(22,8 \%)$ berumur $\geq 40$ tahun.

Tabel 8. Distribusi neonati dengan kelainan bawaan berdasarkan usia ibu

\begin{tabular}{ccc}
\hline Usia (tahun) & Jumlah & $\mathbf{( \% )}$ \\
\hline$\leq 20$ & 9 & 13,6 \\
$21-29$ & 23 & 34,8 \\
$30-39$ & 19 & 28,8 \\
$\geq 40$ & 15 & 22,8 \\
Total & 66 & 100 \\
\hline
\end{tabular}

Dari Tabel 9 didapatkan hasil bahwa terdapat 5 orang ibu $(7,6 \%)$ yang melahirkan neonati dengan kelainan bawaan mempunyai pendidikan terakhir tamat SD, 11 orang ibu $(16,7 \%)$ tamat SMP, 39 orang ibu (59\%) tamat SMA, 1 orang ibu $(1,6 \%) \mathrm{D} 3,8$ orang ibu $(12,1 \%)$ $\mathrm{S} 1$, dan 2 orang ibu (3\%) S2.

Tabel 9. Distribusi neonati dengan kelainan bawaan berdasarkan pendidikan ibu

\begin{tabular}{ccc}
\hline Pendidikan & Jumlah & $\mathbf{( \% )}$ \\
\hline SD & 5 & 7,6 \\
SMP & 11 & 16,7 \\
SMA & 39 & 59 \\
D3 & 1 & 1,6 \\
S1 & 8 & 12,1 \\
S2 & 2 & 3 \\
Total & 66 & 100 \\
\hline
\end{tabular}

Dari Tabel 10 didapatkan bahwa terdapat 48 orang ibu $(72,7 \%)$ yang melahirkan neonati dengan kelainan bawaan bekerja sebagai IRT, 8 orang ibu $(12,1 \%)$ bekerja sebagai PNS, 1 orang ibu $(1,5 \%)$ bekerja sebagai pegawai BUMN, 1 orang ibu $(1,5 \%)$ bekerja sebagai pegawai BLU, 1 orang ibu $(1,5 \%)$ bekerja sebagai honorer, 2 orang ibu (3\%) bekerja sebagai wiraswasta, 3 orang ibu $(4,5 \%)$ bekerja sebagai pegawai swasta, 1 orang ibu $(1,5 \%)$ sebagai mahasiswa, dan 1 orang ibu $(1,5 \%)$ bekerja sebagai buruh.

Berdasarkan Tabel 11 didapatkan hasil bahwa terdapat 60 neonati $(91 \%)$ dengan malformasi tunggal dan 6 neonati (9\%) dengan malformasi multipel. 
Tabel 10. Distribusi neonati dengan kelainan bawaan berdasarkan pekerjaan ibu

\begin{tabular}{ccc}
\hline Pekerjaan & Jumlah & $(\boldsymbol{\%})$ \\
\hline IRT & 48 & 72,7 \\
PNS & 8 & 12,1 \\
Pegawai & & \\
BUMN & 1 & 1,5 \\
Pegawai BLU & 1 & 1,5 \\
Honorer & 1 & 1,5 \\
Wiraswasta & 2 & 3 \\
Swasta & 3 & 4,5 \\
Mahasiswa & 1 & 1,5 \\
Buruh & 1 & 1,5 \\
Total & 66 & 100 \\
\hline
\end{tabular}

Tabel 11. Distribusi neonati dengan kelainan bawaan berdasarkan klasifikasi jumlah kelainan bawaan

\begin{tabular}{ccc}
\hline Klasifikasi & Jumlah & $\mathbf{( \% )}$ \\
jumlah kelainan & & \\
\hline Kelainan tunggal & 60 & 91 \\
Kelainan multipel & 6 & 9 \\
Total & 66 & 100 \\
\hline
\end{tabular}

Berdasarkan Tabel 12 didapatkan hasil bahwa terdapat 54 neonati $(74 \%)$ menderita malformasi mayor dan 19 neonatus (26\%) menderita malformasi minor.

Tabel 12. Distribusi neonati dengan kelainan bawaan berdasarkan klasifikasi berat ringannya kelainan bawaan

\begin{tabular}{ccc}
\hline $\begin{array}{c}\text { Klasifikasi berat } \\
\text { ringannya }\end{array}$ & Jumlah & $\mathbf{( \% )}$ \\
\hline Malformasi & 54 & 74 \\
Mayor & & \\
Malformasi Minor & 19 & 26 \\
Total & 73 & 100 \\
\hline
\end{tabular}

Tabel 13 memperlihatkan bahwa terdapat 27 neonati dengan PJB, 2 neonati dengan hidrosefalus, 4 neonati dengan labiopalatoskizis, 2 neonati dengan labiokizis, 1 neonatus dengan palatokizis, 6 neonati dengan CTEV, 9 neonati dengan mikropenis, 1 neonatus dengan hipospadia, 11 neonati dengan UDT, 1 neonatus dengan Hirschsprung, 2 neonati dengan erbs paralisis, 1 neonatus menderita polidaktili, 3 neonati dengan ginjal polikistik, 1 neoantus dengan mikrotia, 1 neonatus dengan hidrops fetalis, dan 1 neonatus dengan ensefalokel.

Tabel 13. Distribusi neonati dengan kelainan bawaan berdasarkan jenis kelainan bawaan

\begin{tabular}{ccc}
\hline $\begin{array}{c}\text { Jenis kelainan } \\
\text { bawaan }\end{array}$ & Jumlah & $(\boldsymbol{\%})$ \\
\hline Penyakit Jantung & 27 & 37 \\
Bawaan (PJB) & & \\
Hidrosefalus & 2 & 2,7 \\
Labiopalatoskizis & 4 & 5,5 \\
Labioskizis & 2 & 2,7 \\
Palatoskizis & 1 & 1,4 \\
Congenital Talipes & 6 & 8,2 \\
Equinus Varus & & \\
(CTEV) & & \\
Mikropenis & 9 & 12,3 \\
Hipospadia & 1 & 1,4 \\
Undesensus Testis & 11 & 15 \\
$\quad$ (UDT) & & \\
Hirschsprung & 1 & 1,4 \\
Erbs paralisis & 2 & 2,7 \\
Polidaktili & 1 & 1,4 \\
Ginjal Polikistik & 3 & 4,1 \\
Mikrotia & 1 & 1,4 \\
Hydropsfetalis & 1 & 1,4 \\
Ensefalokel & 1 & 1,4 \\
Total & 73 & 100 \\
\hline
\end{tabular}

Dari hasil uji Fisher didapatkan $\mathrm{p}=$ $0,150(>0,050)$ yang menunjukkan tidak terdapat hubungan bermakna antara konsumsi rokok dan alkohol dengan PJB dalam penelitian ini (Tabel 14)

Tabel 14. Hubungan antara penyakit jantung bawaan dengan konsumsi rokok dan alkohol

\begin{tabular}{lcccc}
\hline & \multicolumn{2}{c}{$\begin{array}{c}\text { Kelainan bawaan } \\
\text { PJB }\end{array}$} & P \\
& Tidak & Ya & Total & \\
\hline $\begin{array}{l}\text { Tidak } \\
\text { mengonsumsi }\end{array}$ & 38 & 23 & 61 & \\
$\begin{array}{l}\text { rokok dan } \\
\text { alkohol }\end{array}$ & & & & 0,150 \\
$\begin{array}{l}\text { Mengonsumsi } \\
\text { rokok dan }\end{array}$ & 1 & 4 & 5 & \\
alkohol & & & & \\
Total & 39 & 27 & 66 & \\
\hline
\end{tabular}

Dari hasil uji chi square $\left(\mathrm{X}^{2}\right)$ didapatkan hasil $\mathrm{p}=0,322(>0,05)$ yang 
menunjukkan tidak terdapat hubungan bermakna antara ibu yang menderita infeksi dengan PJB dalam penelitian ini (Tabel 15).

Tabel 15. Hubungan antara penyakit jantung bawaan dengan infeksi ibu selama kehamilan

\begin{tabular}{lcclll}
\hline \multicolumn{1}{c}{$\begin{array}{c}\text { Kelainan bawaan } \\
\text { PJB } \\
\text { Tidak }\end{array}$} & \multicolumn{2}{c}{ Ya } & Total \\
& 29 & 17 & 46 & \\
\hline Tidak terkena & & & & 0,322 \\
infeksi & 10 & 10 & 20 & \\
Terkena infeksi & 39 & 27 & 66 & \\
Total & & & &
\end{tabular}

Dari hasil uji chi square $\left(\mathrm{X}^{2}\right)$ didapatkan hasil $\mathrm{p}=0,436(>0,05)$ yang menunjukkan tidak terdapat hubungan bermakna antara konsumsi obat-obatan dengan PJB dalam penelitian ini (Tabel 16).

Tabel 16. Hubungan antara penyakit jantung bawaan dengan konsumsi obat-obatan

\begin{tabular}{lcccc}
\hline & \multicolumn{2}{c}{ Kelainan Bawaan } & P \\
& \multicolumn{1}{c}{ PJB } & & \\
& 32 & 20 & 52 & \\
\hline $\begin{array}{l}\text { Tidak } \\
\text { mengonsumsi } \\
\text { obat-obatan }\end{array}$ & & & & 0,436 \\
$\begin{array}{l}\text { Mengonsumsi } \\
\text { obat-obatan } \\
\text { Total }\end{array}$ & 7 & 7 & 14 & \\
\hline
\end{tabular}

\section{BAHASAN}

Pada penelitian yang dilakukan secara retrospektif di Bagian Ilmu Kesehatan Anak dan Bagian Ilmu Rekam Medik dalam kurun waktu September 2016November 2016 terdapat 266 neonati dengan diagnosis kelainan bawaan yang tercatat pada periode Januari 2015-Juli 2016 dan hanya 66 neonati yang memenuhi kriteria inklusi.

Berdasarkan distribusi neonati dengan diagnosis kelainan bawaan menurut tahun (Tabel 1), didapatkan bahwa neonati dengan diagnosis kelainan lebih sering terjadi di tahun 2015 yaitu 54 orang $(81,8 \%)$ sedangkan di tahun 2016 (Juli) hanya 12 orang $(18,2 \%)$. Penelitian tahun
2016 hanya dilakukan sampai bulan Juli, hal itu mungkin merupakan salah satu faktor yang menyebabkan kejadian kelainan bawaan tahun 2016 lebih sedikit daripada tahun 2015. Data dari WHO juga menyatakan bahwa pada tahun 2015 ditemukan 303.000 neonati di seluruh dunia yang meninggal kurang dari 4 minggu setelah lahir karena kelainan bawaan. $^{6}$

Berdasarkan distribusi neonati dengan diagnosis kelainan bawaan menurut jenis kelamin (Tabel 2) didapatkan bahwa neonati dengan diagnosis kelainan bawaan lebih sering diderita oleh yang berjenis kelamin laki-laki yaitu 48 orang $(72,7 \%)$ sedangkan neonati yang berjenis kelamin perempuan hanya 18 orang $(27,3 \%)$. Hal ini didukung oleh data dari India yang menunjukkan bahwa neonati berjenis kelamin laki-laki $(2,7 \%)$ lebih berisiko menderita kelainan bawaan daripada neonati berjenis kelamin perempuan $(2,1 \%)$. Penelitian yang dilakukan di India yang lainnya juga menyatakan bahwa neonati berjenis kelamin laki-laki $(1,61 \%)$ sedikit lebih berisiko menderita kelainan bawaan daripada neonati berjenis kelamin perempuan $(1,38 \%))^{7,8}$ Salah satu hal yang menyebabkan laki-laki lebih sering menderita kelainan bawaan ialah jenis kelainan bawaan di bagian kelamin pada laki-laki lebih banyak daripada perempuan yaitu hipospadia, epispadia, mikropenis dan undesensus testis.

Berdasarkan penelitian yang dilakukan pada 66 neonati dengan diagnosis kelainan bawaan hanya ditemukan 3 neonati dengan kehamilan kembar (Tabel 3). Data ini juga selaras dengan penelitian yang dilakukan di Nigeria yaitu dari 1.456 kelahiran dengan kelainan bawaan terdapat 122 neonati dengan kehamilan multipel. ${ }^{9}$ Demikian pula di Tanzania, terdapat 127 kehamilan tunggal dengan kelainan bawaan dan hanya 4 kehamilan multipel dengan kelainan bawaan. ${ }^{10}$ Secara teoritis dijelaskan bahwa kehamilan kembar merupakan salah satu risiko tekanan mekanik yang dapat menyebabkan 
CTEV. ${ }^{11}$ Dari data dan teori diatas menjelaskan bahwa kejadian kelainan bawaan bukan hanya disebabkan oleh kehamilan kembar, akan tetapi ada faktor risiko lain juga yang dapat menyebabkan kelainan bawaan.

Pada distribusi neonati dengan kelainan bawaan berdasarkan faktor risiko mengonsumsi obat-obatan (Tabel 4), aspirin merupakan obat yang paling sering dikonsumsi oleh ibu yang melahirkan bayi dengan kelainan bawaan. Hal ini didukung oleh penelitian lain yang mengemukakan bahwa aspirin berpengaruh terhadap kejadian kelainan bawaan terutama pada PJB dan gastrokizis. ${ }^{12,13}$ Pada penelitian ini, dari hasil uji chi square $\left(\mathrm{X}^{2}\right)$ didapatkan hasil $\mathrm{p}=0,436>0,05$ yang menunjukkan tidak terdapat hubungan bermakna antara konsumsi obat-obatan dengan PJB.

Berdasarkan penelitian yang dilakukan pada 66 neonati dengan diagnosis kelainan bawaan ditemukan 5 ibu yang mengonsumsi rokok dan alkohol (Tabel 5 dan 6). Rokok dan alkohol memang meningkatkan risiko neonatus untuk menderita kelainan bawaan karena di dalamnya mengandung banyak zat yang tidak baik untuk pertumbuhan janin contohnya pada rokok terdapat nitkotin dan karbon monoksida. ${ }^{11}$ Data penelitian yang dilakukan di Lebanon dan Brazil menyatakan bahwa neonatus yang lahir dengan diagnosis kelainan bawaan lebih sering lahir dari ibu yang tidak mengonsumsi rokok dan alkohol. ${ }^{7,14} \mathrm{Hal}$ tersebut dapat terjadi karena neonatus yang lahir dengan kelainan bawaan lainnya dipengaruhi oleh faktor risiko lain atau faktor risiko yang tidak diketahui. ${ }^{11}$

Hasil uji Fisher mendapatkan hasil $\mathrm{p}=$ $0,150>0,05$ yang menunjukkan bahwa tidak terdapat hubungan bermakna antara konsumsi rokok dan alkohol dengan PJB dalam penelitian ini.

Berdasarkan distribusi neonati dengan diagnosis kelainan bawaan menurut ibu yang terkena infeksi (Tabel 7), didapatkan bahwa terdapat 20 ibu yang melahirkan bayi dengan kelainan bawaan menderita infeksi, baik infeksi TORCH maupun infeksi lain. Infeksi yang diderita ibu merupakan faktor risiko yang penting dalam kelahiran bayi dengan kelainan bawaan, infeksi yang diderita oleh ibu apabila tidak ditangani dengan baik maka dapat menyebabkan gangguan pada otak, penglihatan dan pendengaran. ${ }^{11} \mathrm{Hal}$ ini didukung oleh data dari WHO yang menyatakan bahwa infeksi seperti sifilis dan rubela merupakan penyebab penting kelainan bawaan, bahkan pada tahun 2015 di Brazil ditemukan peningkatan kejadian mikrosefalus bagi ibu yang menderita infeksi akibat virus Zika. ${ }^{6,14,15}$

Dari hasil uji chi square $\left(\mathrm{X}^{2}\right)$ didapatkan $\mathrm{p}=0,322>0,05$ yang menunjukkan bahwa tidak terdapat hubungan bermakna antara ibu yang menderita infeksi dengan PJB dalam penelitian ini.

Pada neonati dengan diagnosis kelainan bawaan menurut usia ibu (Tabel 8), didapatkan bahwa usia 21-29 tahun merupakan usia tersering dari ibu yang melahirkan bayi dengan kelainan bawaan (34,8\%), diikuti ibu berusia 30-39 tahun $(28,8 \%)$. Hal ini tidak sejalan dengan teori yang menyatakan bahwa ibu yang berusia $\leq 20$ tahun dan $\geq 40$ tahun lebih berisiko melahirkan bayi dengan kelainan bawaan karena penurunan kualitas sel telur dan fungsi organ reproduksi.

Berdasarkan distribusi neonati dengan diagnosis kelainan bawaan menurut pendidikan ibu (Tabel 9), didapatkan bahwa ibu yang melahirkan bayi dengan kelainan bawaan paling sering memiliki pendidikan akhir tamat SMA yaitu 39 orang, diikuti ibu dengan pendidikan akhir tamat SMP yaitu 11 orang. Hal ini selaras dengan penelitian di Nigeria yang menyatakan bahwa ibu yang memiliki pendidikan akhir tamat SMA atau SMP paling sering melahirkan bayi dengan kelainan bawaan. ${ }^{9}$ Terbatasnya pengetahuan ibu tentang bahaya kehamilan risiko tinggi dan kurangnya kesadaran ibu untuk mendapatkan pelayanan antenatal menyebabkan kejadian kelainan bawaan dan angka kematian perinatal meningkat. ${ }^{11}$ 
Berdasarkan distribusi neonati dengan diagnosis kelainan bawaan menurut pekerjaan ibu (Tabel 10), didapatkan hasil bahwa IRT merupakan pekerjaan tersering oleh seorang ibu yang melahirkan kelainan bawaan yaitu 48 orang $(72,7 \%)$. Masyarakat dengan derajat sosio ekonomi akan menunjukkan tingkat kesejahteraannya dan kesempatannya dalam menggunakan dan menerima pelayanan kesehatan. Pekerjaan ibu maupun suaminya akan mencerminkan keadaan sosio ekonomi keluarga. Data ini didukung oleh data penelitian di Brazil yang menyatakan bahwa IRT merupakan pekejeraan tersering yang ditemukan dari seorang ibu yang melahirkan bayi dengan kelainan bawaan yaitu sekitar $55 \% .^{14}$

Berdasarkan distribusi neonati dengan diagnosis kelainan bawaan menurut klasifikasi jumlah kelainan (Tabel 11), didapatkan hasil bahwa malformasi tunggal hampir terjadi di setiap kelahiran dengan kelainan bawaan yaitu 60 kejadian (91\%), diikuti malformasi multipel dengan 6 kejadian (9\%). Hal ini didukung oleh teori yang menyatakan bahwa sebagaian besar kelainan bawaan terjadi sebagai malformasi tunggal dan sebuah penelitian dari Nigeria juga menyatakan bahwa malformasi tunggal terjadi 36 kali dari total 41 kasus kelainan bawaan yang diteliti. ${ }^{9}$

Berdasarkan distribusi neonati dengan diagnosis kelainan bawaan menurut klasifikasi berat ringannya (tabel 12), didapatkan hasil bahwa malformasi mayor ada 54 orang $(74 \%)$, sedangkan malformasi minor hanya 19 orang $(26 \%)$. Hal ini selaras dengan penelitian dari Nigeria yang menunjukkan bahwa malformasi mayor $(77,8 \%)$ lebih sering terjadi daripada malformasi minor $(22,2 \%) .^{9}$ Malformasi mayor membutuhkan penanganan segera agar supaya tidak menurunkan angka harapan hidup penderita, sedangkan malformasi minor tidak membutuhkan penanganan segera karena sebagian besar hanya berhubungan dengan kosmetik. ${ }^{11}$ Hal ini berarti bahwa kejadian kelainan bawaan di RSUP Prof.
Dr. R. D. Kandou Manado sebagian besar harus ditangani dengan segera karena jika tidak akan membahayakan nyawa dari penderita kelainan bawaan.

Berdasarkan Tabel 13 didapatkan bahwa PJB merupakan jenis kelainan bawaan yang paling sering ditemukan selama penelitian diikuti undesensus testis dan mikropenis. Penyakit jantung bawaan merupakan kelainan bawaan yang sering ditemukan tetapi belum ada teori yang dapat menjelaskan dengan pasti hubungan faktor risiko yang ada dengan kejadian PJB. Undesensus testis dan mikropenis meningkat kejadiannya dalam penelitian ini karena jumlah penderita kelainan bawaan $81 \%$ terdiri dari laki-laki.

\section{SIMPULAN}

Dari hasil penelitian dapat disimpulkan bahwa infeksi ibu selama kehamilan merupakan faktor risiko yang paling sering ditemukan selama penelitian. Selain faktor risiko ibu, terdapat juga faktor risiko kehamilan kembar, faktor risiko teratogen dan faktor risiko yang tidak diketahui yang memengaruhi kejadian kelainan bawaan.

Kelainan bawaan paling sering diderita oleh neonatis berjenis kelamin laki-laki an penyakit jantung bawaan merupakan jenis kelainan bawaan tersering diikuti undesensus testis dan mikropenis.

\section{SARAN}

Perlu dilakukan anamnesis dan pemeriksaan fisik yang lengkap serta pemeriksaan penunjang yang selektif dan efisien terhadap ibu dan neonatus dengan kelainan bawaan.

Seluruh hasil anamnesis, pemeriksaan fisik, dan pemeriksaan penunjang sebaiknya dicatat dengan lengkap dan jelas pada rekam medik ibu dan neonatus sehingga dapat digunakan sebagai bahan pembelajaran dan bahan penelitian.

Perlunya komunikasi, informasi, motivasi, dan edukasi yang baik pada orang tua pasien mengenai pencegahan terhadap faktor risiko yang berhubungan dengan kejadian kelainan bawaan. 
DAFTAR PUSTAKA

1. World Health Organization. Definition of Congenital Anomalies. 2016 September. [cited 2016 August 16]. Available from: http://www.who.int/mediacentre/factshe ets/fs370/en/

2. Taruscio D, Arriola L, Baldi F, Bari-sic I, Bermejo-Sánchez E, Bianchi F, et al. European recommendations for primary prevention of congenital anomalies: a joined effort of EUROCAT and EUROPLAN projects to facilitate inclusion of this topic in the National Rare Disease Plans. Public Health Genomics. 2014;17:115-23.

3. Raza M, Sheikh A, Ahmed S, Ali S,Naqvi S. Risk factors associated with birth defect at a tertiary center in Palistan. Italian Journal of Pediatrics. 2012;38:68.

4. WHO. Birth defects. 2010 April 1; [cit- ed 2016 August 21]. Available from: http://apps.who.int/gb/ebwha/pdf_files/ WHA63/A63_10-en.pdf

5. Maramis $\mathbf{P}$, Kaunang $\mathrm{D}$, Rompis $\mathrm{J}$. Hubungan Penyakit Jantung Bawaan Dengan Status Gizi pada Anak di RSUP Prof. Dr. R. D. Kandou Manado Tahun 2009-2013. eCl. 2014; 2:1-2.

6. WHO. Congenital Anomalies. 2016; [cited 2016 November 9]. Available from: http://www.who.int/mediacentre/factshe ets/fs370/en/

7. Francine R, Pascale S, Aline H. Congenital Anomalies: Prevalences and Risk Factors. Universal Journal of Public Health. 2014;2:58-63.

8. Singh A, Gupta R. Pattern of congenital anomalies in newborn: A hospital based prospective study. JK Science.
2009;11:34-6.

9. Anyanwu LC, Danborno B, Hamman W. Birth prevalance of overt congenital anomalies in Kano Metropolis. Universal Journal of Public Health. 2015;3:89-96.

10. Mashuda F, Zuechner A, Chalya P, Kidenya B, Manyama M. Pattern and factors associated with congenital anomalies among young infants admitted at Bugando Medical Centre, Mwanza, Tanzania. BioMed Central. 2014;7:95.

11. Kosim MS, Yunanto A, Dewi R, Saro-sa G, Usman A. Buku Ajar Neonatologi (1st ed). Jakarta: Ikatan Dokter Anak Indonesia, 2008; p. 41-70.

12. Norgard B, Puho E, Czeizel AE, Skri-ver MV, Sorensen HT. Aspirin use during early pregnancy and risk of congenital abnormalities: A population based case control study. NCBI. 2005;192(3):9223.

13. Drugs. Aspirin Pregnancy and breast-feeding warnings. 2016; [cited 2016 November 9]. Available from: https://www.drugs.com/pregnancy/aspiri n.html

14. Alemida LG, Junior EA, Crott GC, Okido MM, Berezowski AT, Duarte G, et al. Epidemiological risk factor and perinatal outcomes of congenital anomalies. Scielo. 2016;38:348-55.

15. Sunitha T, Prasoona KR, Kumari TM, Srinadh B, Deepika ML, Aruna R, et al. Risk factors for congenital anomalies in high risk pregnant women: A large study from South India. ScienceDirect. 2016;4:1. 